\title{
The Effect of Madrasah Head Leadership Style and Work Motivation on Work Discipline of Madrasah Aliyah Teachers
}

\author{
Elvasusanti, Syamsudduha, Ulfiani Rahman \\ Pascasarjana UIN Alauddin Makssar \\ Email: elvasusanti527@gmail.com
}

(Received: March 15-2019; revised: April 19-2019; published: May 31-2019)

\begin{abstract}
The purpose of this study was to discuss the influence of the leadership style of Madrasah heads and work motivation on the work discipline of Madrasah Aliyah teachers in the North Polongbangkeng District of Takalar District. This study aims to determine the effect of Madrasah head leadership and work motivation on the work discipline of Madrasah teachers. This study uses a type of descriptive and inferential quantitative research. Data collection techniques used in this study were observation, questionnaire and documentation. The population in this study were 101 teachers, with a total sample of 30 teachers from 101 teachers of Madrasah Aliyah Manongkoki, Madrasah Aliyah Muhammadiyah Palleko, Madrasah Aliyah Tarbiyah Islamic Boarding School and Assalam Islamic Boarding School Madrasa in Polongbangkeng District North Takalar District. Based on the results of this study, it is known that the style of Madrasah head leadership has a significant effect on the work discipline of Madrasah Aliyah teachers in Polongbangkeng District. This means that leadership styles must be effective in order to influence the work discipline of teachers. Work motivation towards work discipline of Madrasah Aliyah teachers in Polongbangkeng Subdistrict, if the discipline wants to be improved, the motivation of the teacher's work must also be increased. Together, leadership style and work motivation have a significant effect on the work discipline of Madrasah Aliyah in Polongbangkeng District.
\end{abstract}

Keywords: Leadership Style; Motivation; Work Discipline.

\section{INTRODUCTION}

Education is an important thing in human life, because human education can learn all knowledge. With that knowledge humans can change polapikir, developing to fulfill all their life needs. Life is a dynamic and innovative process, which means that it always changes from time to time, from generation to generation. To be able to survive well and correctly, humans must have knowledge.

Humans who have the knowledge of being honored by Allah Almighty. and His Apostle, as stated in Surah al-Mujāadilah /58:11

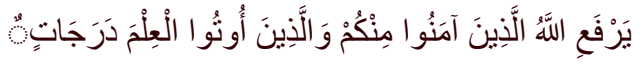

The translation:

... Surely Allah will raise up those who believe among you and those with knowledge of several degrees...(Kementerian Agama, 2012).

Copyright () 2019 Universitas Negeri Makassar. This is an open access article under the CC BY license (http://creativecommons.org/licenses/by/4.0/)

Number: (RISTEKDIKTI) 21/E/KPT/2018 


\section{Jurnal Ilmiah Ilmu Administrasi Publik: Jurnal Pemikiran dan Penelitian Administrasi Publik Volume 9 Number 1, January - Juny 2019. Page 1-8}

The verse above explains the virtues of believers and knowledgeable people, someone who has faith and knowledge will be elevated by Allah SWT. Faith and knowledge are the main capital to be able to achieve success in the world and in the hereafter.

The explanation above indicates the need for an institution as a place to gain knowledge. The container is an educational institution that has a vision. To realize the vision needed a mature mission and planning and active management functions that are related and able to optimize all processes in realizing the vision of the institution.

Madrasah is one of the educational institutions in which there are many human resources (HR) that are the foundation and hope of the realization of the madrasa vision in addition, organizational commitment is a bond that shows employees have a high concern for the organization. Such high concern can be in the form of creativity, discipline, and all attitudes of employees who show concern for the organization. According to Hasibuan (2006) work discipline is a person's awareness and willingness to comply with applicable rules and social norms. Work discipline is also a tool used by managers to be able to communicate with employees to be willing to increase awareness and willingness to fulfill all company regulations (Jumriah, Akib, \& Darwis, 2016; Saleh, 2014; Wairooy, 2017).

According to Darmayanti (2016) that there are several things that affect employee discipline, namely: the size of compensation, the presence or absence of leadership in the company, the presence or absence of rules that can be used as a handle, courageous leadership in taking action, the presence or absence of leadership supervision, There is no concern for the employee.

Employees who have a very important role in the madrasa are educators or teachers. Teachers are required to be disciplined in carrying out their work as a form of commitment to the organization in order to improve performance in teaching (Davari Torshizi \& Bahraman, 2019; Zhu, Wan, Zhou, \& Pan, 2018). However, the principal's leadership style that tends to be uncomfortable with the teachers will trigger the level of discipline of the teacher's work. Leadership style is a pattern of behavior that is designed in such a way as to influence subordinates to maximize the performance of their subordinates (Johannes, 2014: 3). This is in line with the opinion of Mulyasa (2007) which states that leadership style is a way used by leaders to interact with their subordinates (Daryanto, 1998). The head of an unjust madarasah in leading madrasas will have an impact on the discipline of teacher work. The act of disciplining employees must be the same as the implementation, there are several forms of work discipline such as: disciplined discipline, hyperlinkorective, and disciplinary discipline (Syafrina, 2017).

According to Wilson (2012) there are four leadership styles namely directive, supportive, participatory and achievement-oriented leadership. The intended executive is the Leader declaring to subordinates how to carry out a task. This style implies that the leader is resultsoriented. Supportive is meant that the leader tries to get closer to the subordinates and is friendly to the subordinates. Participatory in question is a leader consulting with subordinates to get input and suggestions in the context of decision making. Performance-oriented leadership styles are leaders who set goals that challenge and expect subordinates to try to achieve these goals as optimally as possible. The headmaster's leadership style is one of the important factors that can 
influence the work discipline of the teacher. A good leadership style will be able to have an impact on teacher behavior in carrying out their duties.

Another factor that is very influential in maintaining or improving teacher discipline is the work motivation of teachers because, motivation is a strong drive from within a person to do something (Jamaluddin, Saggaf, \& Rahayu, 2017). Teachers who are not motivated in doing their work will have an impact on discipline even on their own performance. According to Mathis and Jackson in Wilson (2012: 12) that motivation is a desire in someone who causes the person to do a goal. Someone does something for something to achieve the goal. Therefore, motivation is the driver that directs the goal and rarely appears in vain. Encouragement that arises from within a person does not necessarily arise but there are several factors that influence so that the impulse emerges like a need factor that is a need that is not sufficient will give motivation to individuals to do something and desire factors, namely things that encourage individuals to do more than others to get maximum results (Rofiq, 2010).

Likewise with the work environment, facilities that do not support teacher work, the harmony of fellow teachers and employees are able to have an impact on the teacher's work discipline. Likewise with geographical conditions such as locations or madrasa buildings that are so difficult to access, unsafe road conditions and some situations and conditions that do not provide peace and comfort of teachers in the madrasa in doing their work.

Other factors that also influence discipline or whether teachers work are families. Not a few parents who do not like their children become teachers. Teachers are often seen as jobs that do not quickly provide wealth and are even considered gloomy in the future. Or the family has its own reasons that are personal in nature so they do not provide support to their children or partners. This family factor becomes very important for the teacher in carrying out his duties because it can hinder work or give motivation in work. Apart from the above factors there are many other factors that influence the discipline of teacher work such as the state of society, the psychological state of the teacher and others (Akib \& Saleh, 2015; Amirullah \& Darwis, 2015; Nasrullah, Ilmawati, Saleh, Niswaty, \& Salam, 2018).

In view of the importance of the discipline of Aliyah Madrasah teachers in North Polongbangkeng Subdistrict, Takalar District, this article presents the results of research on the influence of Madrasah head leadership and teacher work motivation on the discipline of Madrasah Aliyah teachers in Polongbangkeng Utara District, Takalar District.

\section{METHOD}

This research is an ex post facto quantitative research with correlational analysis. This study examines events that have occurred to determine the effect of leadership style and work motivation on work discipline. This study was conducted at Aliyah Manongkoki Madrasah address at Jl. Kali Dg Jambu No. 141 Solonga, Pangrangnuangku Sub-District, North Polongbangkeng Subdistrict, Takalar District, Muhammadiyah Palleko Aliyah Madrasah address at Jl. Syamsuddin Dg. Ngerang Palleko, North Polongbangkeng Subdistrict, Takalar District, Madrasah Aliyah Tarbiyah Islamic Boarding School is located at Jl. Hj. Manila in Pati Malewang, North Polongbangkeng Subdistrict, Takalar District, and Assalam Islamic Boarding School Madrasah address at Jl. Timbuseng Village Massamaturu Kecamata Polongbangkeng 
4| Jurnal Ilmiah Ilmu Administrasi Publik: Jurnal Pemikiran dan Penelitian Administrasi Publik Volume 9 Number 1, January - Juny 2019. Page 1-8

Utara Takalar Regency. The four Aliyah Madrasas are located in North Polongbangkeng District, Takalar District. Popilation in this study was 101 teachers from the Aliyah Madrasah North Polongbangkeng Subdistrict Takalar with a total sample of 30 teachers from the four Madrasayh Aliyah in Polongbangkeng Utara District Takalar District.

The instruments for collecting data used by researchers are observation sheets, questionnaires and documentation. The data obtained in this study were analyzed using descriptive statistical analysis, namely by describing or giving an overview of the object under study through the data collected. Then inferential analysis was used to generalize the results of research on samples for the population.

\section{RESULT AND DISCUSSION}

Leadership style is a pattern of behavior in leadership of an organization. Madrasah leaders are leaders in an educational institution, namely Madrasas. Madrasah heads in leadership in Madrasahs have a leadership style in leading a Madrasah. The detailed description of the leadership style of the Madrasah Head can be done by looking at the frequency and percentage of answers to each statement then drawing conclusions based on the percentage of overall answers. Thus the frequency and percentage of each question can be used as a reference to describe the leadership style of the Head of Aliyah Madrasah in North Polongbangkeng SubDistrict Takalar District. The choice of answers given to questionnaires by category is always, often, sometimes and not internally. MA teachers in Polongbangkeng Utara Subdistrict Takalar District are: The Madrasah Head made me better understand what I should do as a teacher, the Head of Madrasah did not provide the direction I needed to improve the quality, the Head of Madrasah made me comfortable because of his hospitality, Madrasah Principals included me in activities that related to teacher performance improvement, Madrasah Heads provide incentives for additional activities at Madrasahs, Madrasah Heads conduct Activities in order to improve teacher quality, Madrasah Heads do not conduct consultations if hedak takes policy, Madrasah Heads do not participate the nature of teacher activities in Madrasas, Madrasah Heads direct teachers in making learning administration, Madrasah Heads guide teachers who are still lack of experience in conducting the learning process. The description of each item statement above shows that the leadership style variable of the Madrasah head has a high questionnaire answer score. Overall the leadership style variables have a mean of 51.63 of the 14 statements. This means that the average score of the answers from respondents is 3.68 per statement. This shows that the heads of Aliyah Madrasas in the North Polongbangkeng sub-district of Takalar have a directive, supportive, participatory leadership style and achievement-oriented leadership evidenced by the answers of the teachers on the questionnaire that the researchers spread.

Motivation is one of the most important elements in human resource management, so the leader in an organization should be able to grow the motivation of his subordinates or employees. Organizational motivation is a skill, in directing employees and organizations to work. The description of teacher work motivation in detail can be done by looking at the frequency and percentage of answers to each statement and then drawing conclusions based on the percentage of answers as a whole, the choice of answers given in the questionnaire by 
category always, often, sometimes and not perally. The following are some statements that describe the motivations of Madrasah Aliyah teacher work in Polongbangkeng Utara District, Takalar District. I do not like to work as a teacher, I am happy to carry out activities related to my duties as a teacher, I am diligent in seeking information related to effective learning methods, I do not take part in activities related to learning development, I always make lesson plans before doing learning, I am very eager to provide tutoring for students, I feel that the teacher is a much-needed profession, I receive a salary as a teacher, the salary that I get as a teacher does not meet the needs of the family, I as a teacher gets a professional allowance, the teacher is not paid on time, I always acting according to the teacher's code of ethics, I am not willing to undergo sanctions if I violate the teacher's code of ethics, our fellow teachers support each other in carrying out their duties as teachers. Each item statement above shows that the work motivation variable has a high questionnaire answer score. This is also evidenced by the mean value of 52.20 out of 14 statements. This means that the score score of each statement from the respondent is 3.72. This shows that respondents answered more with scores of scores 3 and 4. Based on the description above, it was shown that the Madrasah Aliyah teachers in the North Polongbangkeng Sub-District of Takalar had high intrinsic and extrinsic motivations in their work. Work discipline is needed by every employee. Discipline becomes a requirement for the formation of attitudes, behaviors, and disciplines of life that will make employees get ease of work, thus creating a conducive working atmosphere and supporting efforts to achieve goals. Descriptions Teacher work discipline in detail can be done by looking at the frequency and the percentage of answers to each statement then draws conclusions based on the percentage of answers as a whole, the choice of answers given to the questionnaire by category always, often, sometimes and not perally. Here are some statements that describe the work discipline of Madrasah Aliyah teachers in North Polongbangkeng Sub-District, Takalar District. I always arrive on time at the Madrasah, I arrive on time at the Madrasah but are late in the Learning process, I never leave the Class during learning hours. , I ask permission from the supervisor to go home early, I end the learning process according to the time specified, Every time I do learning, I use RPP as a guide in learning, I do not attend the Ceremony on Monday if there is another activity, I attach importance to other matters Madrasah meetings, I do not follow the dress code in Madrasah, Follow the rules in Madrasah if it is according to my will. I make RPP before learning begins, RPP that I use in learning has been signed by the Head of Madrasah, I give character assessments to students during learning, I ti not returning learning media that has been used to its original place, I use learning media well and correctly. Each item above statement shows that work discipline variables have a high questionnaire answer score. This is also proven by the mean value of 55.40 out of 15 statements. This means that the score score of each statement from the respondent is 3.69. This shows that respondents answered more with scores of 3 and 4. Based on the description above, it shows that the work discipline variables of Madrasah Aliyah teachers in North Polongbangkeng Subdistrict, Takalar Regency have aspects of respect, respect, obedience, and obey the applicable regulations, both written and unwritten and able to carry it out and not refuse to accept sanctions if he violates the duties and authority given to him.

Based on the description above shows that leadership style and work motivation contribute to discipline or not the teacher in carrying out his duties. Thus the madrasa head is 
6 Jurnal Ilmiah Ilmu Administrasi Publik: Jurnal Pemikiran dan Penelitian Administrasi Publik
Volume 9 Number 1, January - Juny 2019. Page 1-8

expected to continue to improve his leadership style continuously which is believed to be able to influence the teachers in improving the performance of the madrasa.

\section{CONCLUSION}

The leadership style of the Aliyah Madrasah in the North District of Polongbangkeng District has leadership styles that have leadership aspects, directive, supportive, participatory and achievement oriented leadership. In addition, the motivation and work discipline of teachers at the Aliyah Madrasah in North Polongbangkeng Subdistrict, Takalar District are in a very high category. There is also an influence between the leadership style of the Madrasah Aliyah head towards work discipline and teacher motivation.

\section{REFERENCES}

Akib, H., \& Saleh, S. (2015). Pengaruh Kepala Sekolah Sebagai Supervisor Terhadap Kinerja Guru Di Smk Negeri 7 Makassar. Jurnal Office, 1(2), 141-147.

Amirullah, A. H., \& Darwis, M. (2015). Kompetensi Kepribadian Guru Dalam Meningkatkan Prestasi Belajar Siswa Kelas Xii Smk Negeri 2 Pinrang. Jurnal Office, 1(2), 148-152.

Darmayanti, E. (2016). Analisis Faktor-Faktor Penentu Disiplin Kerja Aparatur Sipil Negara Di Kabupaten Nunukan. Universitas Terbuka.

Daryanto, H. M. (1998). Administrasi pendidikan. PT Rineka Cipta.

Davari Torshizi, M., \& Bahraman, M. (2019). I explain, therefore I learn: Improving students' assessment literacy and deep learning by teaching. Studies in Educational Evaluation, 61, 66-73. https://doi.org/https://doi.org/10.1016/j.stueduc.2019.03.002

Hasibuan, M. S. P. (2006). Manajemen Dasar, Pengertian, dan Masalah, Edisi Revisi. Jakarta: Bumi Aksara.

Jamaluddin, J., Saggaf, S., \& Rahayu, S. (2017). Kedisiplinan Aparatur Sipil Negara pada Kantor Badan Kependudukan dan Keluarga Berencana Nasional Provinsi Sulawesi Selatan. Jurnal Ilmiah Ilmu Administrasi Publik, 7(1), 25-29.

Jumriah, J., Akib, H., \& Darwis, M. (2016). Disiplin Kerja Guru Dalam Melaksanakan Tugas Pembelajaran Di Sekolah Menengah Kejuruan Negeri 1 Barru. Jurnal Office, 2(2), 155162.

Kementerian Agama, R. I. (2012). al-Qur'an dan Terjemahnya. Jakarta: Sinergi Pustaka Indonesia.

Mulyasa, E. (2007). Menjadi kepala sekolah profesional. Bandung: Remaja Rosdakarya.

Nasrullah, M., Ilmawati, I., Saleh, S., Niswaty, R., \& Salam, R. (2018). Minat Menjadi Guru Pada Mahasiswa Program Studi Pendidikan Administrasi Perkantoran Fakultas Ilmu Sosial Universitas Negeri Makassar. Jurnal Ad'ministrare, 5(1), 1-6. 
Rofiq, M. N. (2010). Pembelajaran kooperatif (cooperative learning) dalam pengajaran pendidikan agama Islam. Jurnal Falasifa, 1(1), 1-14.

Saleh, S. (2014). Penegakan Disiplin (Suatu Upaya Peningkatan Kinerja Pegawai). Jurnal Ad'ministrare, 1(1), 8-19.

Syafrina, N. (2017). Pengaruh disiplin kerja terhadap kinerja karyawan pada pt. suka fajar pekanbaru. Eko Dan Bisnis: Riau Economic and Business Review, 8(4), 1-12.

Wairooy, A. (2017). Pengaruh Disiplin Kerja dan Kompensasi Terhadap Kinerja Karyawan pada PT. Pertamina (Persero), Tbk. Pemasaran Region VII Makassar. Jurnal Ad'ministrare, 4(1), 15-24.

Wilson, B. (2012). Manajemen Sumber Daya Manusia, Penerbit Erlangga, Jakarta.

Zhu, W., Wan, M., Zhou, Y., \& Pan, W. (2018). Fuzzy computation of teaching performance based on data envelopment analysis method. Cognitive Systems Research, 52, 351-358. https://doi.org/https://doi.org/10.1016/j.cogsys.2018.07.018 
8| Jurnal Ilmiah Ilmu Administrasi Publik: Jurnal Pemikiran dan Penelitian Administrasi Publik Volume 9 Number 1, January - Juny 2019. Page 1-8 